\title{
Karakteristik Kimia dan Organoleptik Sirup Gandaria dengan Penambahan Konsentrasi Gula
}

\section{Chemical Characteristics and Organoleptics of Gandaria Sirup with Addition of Sugar Concentration}

\section{Rachel Breemer*, Syane Palijama, Julius Jambormias}

\author{
Jurusan Teknologi Hasil Pertanian, Fakultas Pertanian, Universitas Pattimura, Jl. Ir. M. Putuhena, Kampus \\ Poka, Ambon 97233
}

*Penulis korespondensi: R. Breemer, e-mail: rachelbreemer@gmail.com

Tanggal submisi: 3 November 2020; Tanggal penerimaan: 23 Maret 2021

\begin{abstract}
"Gandaria" fruit is a seasonal fruit that is easy to prepare but cannot be kept fresh for a long time. Processing technology is important for creating a food product with a longer shelf life and being consumed outside of the season. Processing "gandaria" into syrup is one of the methods. The syrup has a thick and distinctive taste characteristic because it contains 55-65\% sugar. This study aimed to determine what sugar concentration is best for producing good "gandaria" fruit syrup. A completely randomized experimental design with one factor, namely the concentration of sugar, i.e., 50\%, 55\%, 60\%, 65\%, and 70\% repeated three times, was applied in this research. The results showed that sugar concentration treatment produced syrup with total sugar 59,36-65,97\%, total acidity 13.48-17.35\%. vitamin C 16.47-16.97\%, and total soluble solid 39.27-46.43\%. Organoleptic characteristics, namely color (rather yellow to yellow), aroma (slightly gandaria aroma), taste (slightly gandaria taste to gandaria taste), thickness (somewhat like to like), overall (somewhat like to like). The best sugar concentration in producing good gandaria syrup was $70 \%$.
\end{abstract}

Keywords: Gandaria; sugar concentration; syrup

(C) The Authors. Publisher Universitas Pattimura. Open access under CC-BY-SA license

\begin{abstract}
ABSTRAK
Buah gandaria merupakan buah musiman yang mudah dan tidak dapat dikonsumsi dalam bentuk segar dalam waktu yang lama. Penerapan teknologi pengolahan sangat penting untuk menghasilkan produk pangan olahan yang memiliki daya simpan yang lebih lama dan dapat dikonsumsi diluar musim salah satunya adalah mengolah gandaria menjadi sirup. Sirup memiliki karakteristik yang kental dan rasa yang khas karena mengandung gula 55-65\%. Penelitian ini bertujuan untuk menentukan konsentrasi gula yang tepat dalam menghasilkan sirup buah gandaria yang baik. Rancangan percobaan yang digunakan dalam penelitian ini adalah rancangan acak lengkap dengan satu faktor yaitu konsentrasi gula 50\%, 55\%, 60\%, 65\% dan 70\%, masing-masing perlakuan diulang sebanyak tiga kali. Hasil menunjukkan bahwa perlakuan konsentrasi gula $55-70 \%$ menghasilkan total gula sebesar 59,36-65,97\%, total asam sebsesar 17,35-13,48\%, vitamin C sebesar 16,97-16,47\%, dan total padatan terlarut sebesar 39,27-46,43\%, dan karakteristik organoleptik warna (agak kuning-kuning), aroma (agak beraroma gandaria), rasa (agak berasa gandaria-berasa ngandaria), kekentalan (agak suka-suka), overall (agak suka-suka). Salah satu perlakuan konsentrasi terbaik adalah perlakuan konsentrasi gula $70 \%$.
\end{abstract}

Kata kunci: Gandaria; konsentrasi gula; sirup

(c) Penulis. Penerbit Universitas Pattimura. Akses terbuka dengan lisensi CC-BY-SA. 


\section{PENDAHULUAN}

Gandaria (Bouea macrophylla Griffith) adalah salah satu tanaman asli Indonesia yang termasuk dalam kelompok Anacardiaceae yang tersebar dibeberapa daerah seperti Aceh, Pekanbaru, Palembang, Bogor, Kalimantan dan Ambon (Harsono et al., 2016). Tanaman gandaria memiliki karakteristik buah yang masih muda yaitu memiliki kulit buah berwarna hijau, beraroma netral, serta memiliki rasa yang asam dan biasanya diolah menjadi rujak, asinan dan sambal (Rajan dan Bhat, 2017). Buah gandaria tidak dapat dikonsumsi dalam bentuk segar dalam waktu yang lama setelah dipetik sehingga biasanya diolah menjadi produk baru seperti selai, sari buah, sirup dan sebagainya. Vitamin yang terkandung dalam buah gandaria bermanfaat bagi kesehatan antara lain: untuk menangkal radikal bebas dan menghambat penuaan dini. Buah gandaria mengandung $85 \mathrm{~g}$ air, $12 \mathrm{mg}$ protein, $600 \mathrm{mg}$ serat, $230 \mathrm{mg}$ abu, asam amino esensial, mineral kalium yang berlimpah, kalsium, forfor, besi, natrium, karoten, vitamin A, B1, B2, $\mathrm{C}$, niacin, lutein, kriptosantin, $\alpha$ dan $\beta$ karoten, tiamin, riboflavin (Rajan et al., 2014).

Ketersediaan buah ini tergantung musim dan masyarakat hanya mengkonsumsi buah ini dalam bentuk segar sehingga banyak buah yang terbuang karena mempunyai sifat yang mudah rusak. Penerapan teknologi pengolahan sangat penting untuk menghasilkan produk pangan olahan yang memiliki daya simpan yang lebih lama dan dapat dikonsumsi di luar musim. Salah satu upaya untuk mempertahakankan mutu dan memperpanjang umur simpan buah gandaria adalah dengan mengolah menjadi produk baru seperti selai (Minh, 2014), nata buah gandaria (Warella et al., 2016), sirup dan sebagainya.

Sirup adalah sejenis minuman ringan berupa larutan kental dengan cita rasa yang berbeda serta memiliki aroma khas yang mampu memberikan kesegaran bagi orang yang mengkonsumsinya. Penggunaan sirup tidak langsung diminum tetapi harus diencerkan terlebih dahulu karena memiliki kandungan gula yang tinggi yaitu 55-65\% (Andrea et al., 2016). Salah satu faktor penting yang berpengaruh terhadap mutu sirup adalah konsentrasi gula yang digunakan karena gula dapat berfungsi sebagai pemanis maupun pengawet sehingga dapat meningkatkan mutu dan memperpanjang umur simpan. Gula berperan dalam memperbaiki cita rasa dan aroma dengan cara membentuk keseimbangan antara rasa asam dan rasa manis (Zaitoun et al., 2018).
Penambahan gula pada pembuatan sirup telah dikaji melalui beberapa penelitian sebelumnya pada sirup buah tamarillo dengan konsentrasi gula $80 \%$ menghasilkan mutu sirup yang baik (Pratama et al., 2012). Pada sirup air kelapa dimana penambahan gula sebanyak $65 \%$ menghasilkan sirup dengan karakteristik yang baik (Marwanto et al., 2016). Hadiwijaya (2013) melakukan penelitian mengenai pengaruh penambahan gula terhadap karakteristik sirup buah naga merah dengan rasio konsentrasi penambahan gula sebesar 50, 55 dan $65 \%$. Sirup buah naga yang dihasilkan dari penambahan gula 50\% telah memenuhi standar mutu sirup SNI (2013) yaitu diperoleh kadar gula sebesar $65,65 \%$. Pembuatan sirup gandaria dengan penambahan gula yang berbeda bertujuan untuk menentukan berapa konsentrasi gula yang tepat dalam menghasilkan kualitas sirup gandaria dengan karkateristik kimia dan organoleptik yang baik.

\section{METODE PENELITIAN}

\section{Bahan}

Bahan yang digunakan dalam pembuatan sirup adalah buah gandaria yang diperoleh dari Desa Rumahtiga, Kecamatan Teluk Ambon dengan tingkat kematangannya masak.

\section{Pembuatan Sirup Gandaria}

Proses pembuatan sirup gandaria mengacu pada Pujimulyani (2009) sebagai berikut: buah gandaria disortasi dan dikupas untuk memisahkan daging dari bijinya kemudian dilakukan proses penghancuran menggunakan crusher dan ditambahkan air dengan perbandingan 2:1 (air:daging buah) sehingga menghasilkan bubur buah gandaria. Bubur buah kemudian diukur sebanyak $3.000 \mathrm{~mL}$ dan ditambahkan asam sitrat $0,1 \%$ (Koepoe koepoe, Indonesia) dan gula (Gulaku, Indonesia) sesuai perlakuan dan dimasak hingga mendidih. Sirup diangkat dan kemudian didinginkan pada suhu ruang, sirup kemudian disaring menggunakan kain saring dan dikemas menggunakan botol kaca yang telah disterilkan.

\section{Uji Organoleptik}

Uji mutu hedonik dilakukan terhadap warna, aroma dan rasa sedangkan untuk kekentalaan dan overall menggunakan uji hedonik. Sampel disajikan kepada 30 orang panelis secara acak menggunakan skala hedonik, skala mutu hedonik dan skala numerik secara visual dengan memberi- 
kan kode tertentu pada hasilnya dan dinyatakan dalam angka yang menunjukkan nilai.

\section{Analisis Kimia}

\section{Analisis pH (Ibrahim, 2016)}

$\mathrm{pH}$ diukur menggunakan alat $\mathrm{pH}$ meter (Ezdo 5011, Taiwan). Sampel sebanyak $30 \mathrm{~mL}$ dimasukkan ke dalam gelas beaker $50 \mathrm{~mL}$. Sebelum $\mathrm{pH}$ digunakan, terlebih dahulu dikalibrasi menggunakan larutan buffer $\mathrm{pH} 7$ (Merck, Jerman) dan dibersihkan dengan akuades, selanjutnya dilakukan pengukuran $\mathrm{pH}$ terhadap sampel.

\section{Analisis Total Gula (Sudarmadji et al., 1997)}

Sebanyak $10 \mathrm{~g}$ bahan ditimbang dan ditambahkan ke dalam labu ukur $100 \mathrm{~mL}$ dan ditambahkan $50 \mathrm{~mL}$ akuades. Pb-asetat (Merck, Jerman) ditambahkan tetes demi tetes sampai penetesan dari reagen tidak menimbulkan pengeruhan kembali, lalu ditambahkan akuades hingga tanda batas dan disaring. Filtrat ditampung dalam labu takar $200 \mathrm{~mL}$. Kelebihan $\mathrm{Pb}$ dihilangkan dengan ditambahkan $\mathrm{Na}_{2} \mathrm{CO}_{3}$ anhidrat (Merck, Jerman) secukupnya, kemudian ditambah akuades sampai tanda batas, digojog dan disaring. Filtrat bebas $\mathrm{Pb}$ bila ditambah $\mathrm{Na}_{2} \mathrm{CO}_{3}$ anhidrat tetap jernih. Sebanyak $25 \mathrm{~mL}$ filtrat bebas $\mathrm{Pb}$ dipipet ke dalam labu erlenmeyer dan ditambahkan $25 \mathrm{~mL}$ larutan LuffSchoorl (Merck, Jerman). Selain itu, blanko juga dipersiapkan yaitu $25 \mathrm{~mL}$ larutan Luff-Schoorl dengan $25 \mathrm{~mL}$ akuades. Setelah ditambah beberapa butir batu didih, labu erlenmeyer dihubungkan dengan pendingin balik, kemudian didihkan. Pendidihan larutan dipertahankan selama 10 menit. Tahapan berikutnya, didinginkan dan ditambahkan 15 mL KI 20\% (Merck, Jerman) dan dengan hatihati ditambahkan $25 \mathrm{~mL} \mathrm{H}_{2} \mathrm{SO}_{4}$ 26,5\% (Merck, Jerman). Iodium yang dibebaskan lalu dititrasi dengan larutan natrium tiosulfat $0,1 \mathrm{~N}$ (SigmaAldric, New Zealand) menggunakan indikator pati sebanyak 2-3 mL. Untuk memperjelas perubahan warna pada akhir titrasi maka sebaiknya pati diberikan pada saat titrasi hampir berakhir.

\section{Total asam (AOAC, 2005)}

Sampel sebanyak $10 \mathrm{~g}$ dimasukkan kedalam labu takar $100 \mathrm{~mL}$ dan ditambahkan akuades dan ditempatkan sampai tanda tera, lalu dikocok dan disaring dengan kertas saring biasa. Hasil saringan diambil sebanyak $50 \mathrm{~mL}$ dan diteteskan indikator pp (Merck, Jerman) lalu dititrasi dengan $\mathrm{NaOH} \mathrm{0,1}$ $\mathrm{N}$ (Riede-deHaén, Jerman).

$$
\text { Total asam }(\%)=\frac{m L \text { NaOh } \times N ~ N a O H}{\text { bobot sampel }} \times 100 \%
$$

\section{Vitamin C (AOAC, 2005)}

Sampel sebanyak $10 \mathrm{~mL}$ dimasukkan kedalam labu takar $100 \mathrm{ml}$ dan tambahkan akudes sampai tanda tera. filtrat diambil $25 \mathrm{~mL}$ dan ditetesi $1 \mathrm{~mL}$ amilum (Merck, Jerman) dan dititrasi dengan KI 0,1 N (Merck, Jerman) hingga terjadi perubahan warna. Perhitungan vitamin $\mathrm{C}$ dengan rumus sebagai berikut:

$$
\text { Vitamin C }(\%)=\frac{m L K I \times 0,88 \times f p}{\text { berat sampel }} \times 100 \%
$$

Keterangan: $f p=$ faktor pengenceran

\section{Total Padatan Terlarut (Magwaza dan Opara, 2015)}

Sampel diambil bahan dengan menggunakan pipet tetes dan diteteskan di atas kaca hand refractometer $\mathrm{N}-2 \mathrm{e}$ (Atago, Jepang) lalu dilihat titik terang dan gelapnya. Angka yang tertera tersebut merupakan total padatan terlarut ( $\left.{ }^{\circ} \mathrm{Brix}\right)$.

\section{Analisis Data}

Penelitian ini menggunakan rancangan acak lengkap dengan satu faktor yaitu konsentrasi gula yang terdiri dari lima taraf perlakuan yaitu konsentrasi gula 50, 55, 60, 65, dan $70 \%$ dengan masing-masing taraf perlakuan diulang sebanyak tiga kali. Data hasil analisis kimia diuji secara statistik menggunakan Minitab versi 18,0. Bila terdapat pengaruh perlakuan, maka pengujian dilanjutkan dengan uji beda nyata jujur pada taraf $95 \%(\alpha=0,05)$. Sedangkan untuk uji organoleptik dianalsis secara deskriptif.

\section{HASIL DAN PEMBAHASAN}

\section{Karakteristik Kimia}

\section{Total Gula}

Total gula merupakan campuran gula reduksi dan nonreduksi hasil hidrolisa pati. Pengukuran total gula dilakukan untuk mengetahui kandungan gula di dalam suatu bahan pangan karena total gula dapat menentukan sifat-sifat dalam bahan pangan.

Hasil analisis keragaman menunjukkan bahwa perlakuan penambahan gula berpengaruh sangat nyata $(p<0,01)$ terhadap total gula sirup gandaria. Hasil analisis menunjukkan bahwa nilai rataan total gula tertinggi pada perlakuan konsentrasi gula $70 \%$ yaitu sebesar $65,97 \%$ dan berbeda nyata dengan semua perlakuan lainnya sedangkan nilai rataan total gula terendah terdapat 
pada perlakuan konsentrasi gula 50\% yaitu 59,36\% dan tidak berbeda nyata dengan perlakuan konsentrasi gula $55 \%$ tetapi berbeda nyata dengan perlakuan konsentrasi gula lainnya.

Hasil menunjukkan bahwa semakin tinggi konsentrasi gula yang ditambahkan semakin tinggi total gula pada sirup buah gandaria. Hal ini disebabkan oleh larutan gula yang ada merupakan gula yang terdiri dari beberapa komponen sehingga dengan penambahan gula dari luar maka dengan sendirinya akan bertambah bagian total gulanya sehingga total gula dari sirup semakin tinggi. Hal ini sejalan dengan penelitian yang dilakukan oleh Hadiwijaya (2013) dan Melisa dan Mardesci (2016) pada sirup buah kelubi. Semakin tinggi konsentrasi gula yang ditambahkan, total gula sirup buah naga merah semakin meningkat Hadiwijaya (2013).

Menurut SNI (2013) kadar gula minimal pada sirup adalah sebesar $65 \%$ dan dari kelima perlakuan yang dilakukkan hanya terdapat satu perlakuan yang memenuhi syarat SNI sirup yaitu perlakuan konsentrasi gula $70 \%$ sebesar $65,97 \%$ sedangkan perlakuan lainnya belum memenuhi standar SNI. Hal ini disebabkan oleh rendahnya konsentrasi gula yang ditambahkan pada keempat perlakuan yaitu konsentrasi gula 50, 55, 60, dan $65 \%$. Hasil menunjukkan bahwa semakin tinggi konsentrasi gula yang ditambahkan maka total gula akan semakin meningkat. Peningkatan ini disebabkan karena ketika dipanaskan gula akan mengalami hidrolisis menjadi gula invert, gula invert akan menentukan total gula dalam produk dimana semakin tinggi jumlah gula invert yang terbentuk total gula akan meningkat (Akal et al., 2018).

\section{Derajat Keasaman (pH)}

$\mathrm{pH}$ adalah derajat keasaman yang digunakan untuk menyatakan tingkat keasaman atau kebasaan yang dimiliki oleh suatu larutan. Hasil analisis keragaman menunjukkan bahwa perlakuan penambahan konsentrasi gula tidak berpengaruh nyata terhadap $\mathrm{pH}$ sirup gandaria. Hasil analisis menunjukkan bahwa nilai rataan $\mathrm{pH}$ sirup gandaria tertinggi terdapat pada perlakuan kosentrasi gula $50 \%$ yaitu sebesar $2,93 \%$ sedangkan nilai rataan $\mathrm{pH}$ terendah terdapat pada perlakuan kosentrasi gula 55,65 dan $70 \%$ yaitu 2,87 . Hal ini menunjukkan bahwa kosentrasi gula yang ditambahkan tidak mempengaruhi $\mathrm{pH}$ sirup gandaria. Menurut Masriatini (2018) gula mempunyai peran yang sedikit dalam memberikan pengaruh terhadap $\mathrm{pH}$ dari sirup. $\mathrm{pH}$ sirup sangat bergantung pada waktu pemasakkan, suhu dan asam alami dari bahan baku serta penambahan asam seperti asam sitrat (Hadiwijawa, 2013).

\section{Total Asam}

Uji keasaman dilakukan untuk mengetahui tingkat keasaman pada sirup gandaria. Perlakuan penambahan gula dapat menurunkan tingkat keasaman sirup gandaria. Hasil analisis keragaman menunjukkan bahwa perlakuan penambahan gula berpengaruh sangat nyata $(P<0,01)$ terhadap total asam sirup gandaria. Hasil analisa total asam sirup gandaria seperti yang terlihat pada Tabel 1, menunjukkan bahwa nilai rataan tertinggi terdapat pada perlakuan konsentrasi gula $55 \%$ yaitu sebesar $17,38 \%$ dan berbeda nyata dengan perlakuan konsentrasi gula $70 \%$, tetapi tidak berbeda nyata dengan perlakuan konsentrasi gula lainnya, sedangkan nilai rataan total asam terendah terdapat pada perlakuan gula $70 \%$ yaitu sebesar $13,48 \%$ serta tidak berbeda nyata dengan perlakuan konsentrasi gula $60 \%$ dan $65 \%$. Hal ini menunjukkan bahwa semakin tinggi konsentrasi gula yang ditambahkan semakin rendah total asam sirup gandaria.

Menurunnya nilai total asam disebabkan karena gula yang ditambahkan dalam konsentrasi tinggi sehingga total asam pada sirup menjadi menurun seiring dengan meningkatnya konsentrasi gula. Menurut Bastanta et al. (2017) konsentrasi gula dapat menurunkan total asam sirup campuran sirsak dan bit, tetapi total asam sirup biasanya dipengaruhi oleh kandungan asam alami yang terdapat pada jenis buah yang digunakan.

Tabel 1. Pengaruh konsentrasi gula terhadap karakteristik kimia sirup gandaria

\begin{tabular}{|c|c|c|c|c|c|}
\hline \multirow{2}{*}{ Parameter } & \multicolumn{5}{|c|}{ Konsentrasi Gula (\%) } \\
\hline & 50 & 55 & 60 & 65 & 70 \\
\hline Total gula & 59,36 & 60,60 & 63,09 & 63,27 & 65,97 \\
\hline$(\%)$ & $\mathrm{c}$ & c & $\mathrm{b}$ & $\mathrm{b}$ & a \\
\hline $\mathrm{pH}$ & 2,93 & 2,87 & 2,90 & 2,87 & 2,87 \\
\hline Tota & 17,35 & 17,38 & 16,34 & 14,99 & 13,48 \\
\hline Asam (\%) & $\mathrm{a}$ & $a b$ & $\mathrm{bc}$ & $\mathrm{bc}$ & $\mathrm{c}$ \\
\hline Vitamin $\mathrm{C}$ & 16,97 & 16,74 & 16,68 & 16,55 & 16,47 \\
\hline$(\%)$ & $\mathrm{a}$ & $\mathrm{a}$ & $\mathrm{a}$ & $\mathrm{a}$ & a \\
\hline Total & & & & & \\
\hline Padatan & 39,27 & 42,97 & 44,40 & 45,77 & 46,43 \\
\hline $\begin{array}{l}\text { Terlarut } \\
\left({ }^{\circ} \text { Brix }\right)\end{array}$ & $\mathrm{b}$ & $\mathrm{a}$ & $\mathrm{a}$ & $\mathrm{a}$ & $\mathrm{a}$ \\
\hline
\end{tabular}

Keterangan: Angka yang diikuti huruf yang sama menyatakan tidak berbeda nyata pada uji beda nyata jujur $(\alpha=$ $0,05)$. 
Kandungan asam alami yang kuat dapat meningkatkan total asam sirup. Buah gandaria diduga memiliki kandungan asam alami yang lemah sehingga dengan penambahan gula yang tinggi total asam sirup menurun. Hal yang sama juga dilaporkan oleh Ahmed et al. (2016) total asam akan menurun seiring dengan meningkatnya konsentrasi gula yang ditambahkan.

\section{Vitamin C}

Kadar vitamin $\mathrm{C}$ merupakan salah satu jenis vitamin yang larut dalam air dan mamiliki peranan penting dalam menangkal berbagai penyakit. Vitamin $\mathrm{C}$ dikenal dengan nama kimia dari bentuk utamanya yaitu asam askorbat. Hasil analisis keragaman menunjukkan bahwa perlakuan penambahan gula tidak berpengaruh nyata terhadap nilai kadar vitamin $\mathrm{C}$ sirup gandaria. Hasil analisa kadar vitamin $\mathrm{C}$ seperti yang terlihat pada Tabel 1 menunjukkan bahwa nilai rataan vitamin $\mathrm{C}$ tertinggi terdapat pada perlakuan penambahan konsentrasi gula $50 \%$ yaitu sebesar $16,97 \%$, sedangkan nilai rataan terendah terdapat pada perlakuan penambahan konsentrasi gula $70 \%$ yaitu sebesar $16,47 \%$.

Menurut Hadiwijaya (2013) gula bukanlah sumber vitamin $\mathrm{C}$ sehingga penambahan gula pada pembuatan sirup gandaria tidak berpengaruh terhadap kandungan vitamin C. Menurut Rajan dan Bhat (2016) kadar vitamin $\mathrm{C}$ pada buah gandaria matang berkisar antara 27,79-41,69 mg lebih rendah jika dibandingkan dengan buah gandaria yang belum matang yaitu 75,44-99,27 mg. vitamin C sirup mengalami penurunan seiring dengan penambahan gula hal ini disebabkan oleh gula dapat berdifusi dengan kedalam campuran sari buah dan mengekstrak vitamin C karena gula akan membuat air dengan mudah masuk dan melarutkan vitamin C. Vitamin C larut air akan menguap bersama air pada proses pemanasan (Hui et al., 2006).

\section{Total Padatan Terlarut}

Uji total padatan terlarut ini dilakukan untuk mengetahui seberapa besar padatan yang larut pada sirup. Hasil analisis keragaman menunjukkan bahwa perlakuan penambahan gula berpengaruh sangat nyata $(P<0,01)$ terhadap nilai total padatan terlarut sirup gandaria. Hasil analisa total padatan terlarut sirup gandaria seperti yang terlihat pada Tabel 1 menunjukkan bahwa nilai rataan total padatan terlarut tertiggi terdapat pada perlakuan konsentrasi gula $70 \%$ yaitu sebesar $46,43 \%$, serta berbeda nyata dengan perlakuan konsentrasi gula $50 \%$ namun tidak berbeda nyata dengan perlakuan konsentrasi gula lainnya. Sedangkan nilai rataan terendah total padatan terlarut sirup gandaria terdapat pada perlakuan konsentrasi gula 50\% yaitu sebesar 39,27\% serta berbeda nyata dengan perlakuan konsentrasi gula lainnya.

Hasil analisis menunjukkan bahwa semakin tinggi konsentrasi gula maka total padatan terlarut semakin tinggi. Hasil ini sejalan dengan penelitian Melisa dan Mardesci (2016) pada sirup buah kelubi, Bastanta et al. (2017) pada sirup campuran buah sirsak dan bit. Meningkatnya nilai total padatan terlarut disebabkan oleh kelarutan gula dalam air yang besar pada suhu pemasakan yang tinggi dan gula juga merupakan fraksi padat, sehingga semakin banyak konsentrasi gula yang ditambahkan maka total padatan yang dihasilkan juga semakin meningkat. Peningkatan total padatan terlarut disebabkan oleh sifat gula yang mudah larut dalam air sehingga semakin banyak konsentrasi gula yaang ditambahkan maka semakin meningkatkan total padatan terlarut dari sirup buah gandaria yang dihasilkan. Komponen-komponen yang terukur sebagai total padatan terlarut yaitu sukrosa, gula pereduksi, asam organik, mineral, pigmen dan protein (Magwaza dan Opara, 2015).

\section{Karakteristik Organoleptik}

\section{Warna}

Warna merupakan salah satu parameter yang mudah untuk menilai suatu produk pangan. Warna pula dapat mengindikasi suatu produk pangan yang diamati (Hidayat et al., 2018). Hasil penelitian panelis terhadap warna sirup gandaria menunjukkan bahwa perlakuan konsentrasi gula $55 \%$ nilai warna adalah 3,5 dengan kriteria sangat kuning sedangkan untuk perlakuan konsentrasi gula 50, 60 , 65, dan $70 \%$ nilai warna berturut-turut 3,30 , 3,06, 3,03 dan 2,8 dengat kriteria warna kuning. Hal ini diduga disebabkan karena pigmen xantofil yang terdapat pada gandaria menurun dengan adanya penambahan gula. Hal serupa juga sejalan dengan penelitian yang dilakukan oleh Fitri et al. (2017) bahwa selama proses pemasakan kerusakan utama terjadi pada gula dan perubahan warna yang terjadi disebabkan oleh reaksi karamelisasi yaitu reaksi pencoklatan non enzimatis yang meliputi degradasi gula tanpa asam amino jika gula dipanaskan diatas titik cairnya sehingga warna asli pada buah-buahan setelah dimasak akan mengalami perubahan warna. 
Tabel 2. Pengaruh konsentrasi gula terhadap karakteristik organoleptik sirup gandaria

\begin{tabular}{lccccc}
\hline & \multirow{2}{*}{ Parameter } & \multicolumn{5}{c}{ Konsentrasi Gula (\%) } \\
\cline { 2 - 6 } & 50 & 55 & 60 & 65 & 70 \\
\hline Warna & 3,30 & 3,50 & 3,06 & 3,03 & 2,80 \\
Aroma & 2,70 & 2,83 & 2,80 & 2,70 & 2,43 \\
Rasa & 3,25 & 3,26 & 3,36 & 3,03 & 2,93 \\
Kekentalan & 2,93 & 3,10 & 2,73 & 2,70 & 2,10 \\
Overall & 3,10 & 3,30 & 3,16 & 2,93 & 2,73 \\
\hline
\end{tabular}

\section{Aroma}

Aroma disebut juga pencicipan jarak jauh dengan menggunakan indera penciuman. Manusia dapat mengenal enaknya makanan yang belum terlihat hanya dengan mencium bau atau aroma makanan tersebut dari jarak jauh (Nurwin et al., 2019).

Hasil penilaian panelis terhadap aroma sirup gandaria menunjukkan bahwa perlakuan konsentrasi gula 50, 55, 60dan $65 \%$, nilai aroma berturutturut adalah 2,70,2,83, 2,80 dan 2,70 dengan kriteria beraroma gandaria sedangkan untuk perlakuan konsentrasi gula $70 \%$ nilai aroma 2,43 dengan kriteria agak beraroma gandaria. Penelitian ini sejalan dengan Hadiwijaya (2013) yang menyatakan bahwa pada dasarnya penambahan gula tidak memberikan banyak pengaruh terhadap aroma karena gula tidak memiliki aroma yang menonjol dan kuat.

\section{Rasa}

Rasa merupakan salah satu atribut penilaian organoleptik yang sulit karena menilai karakteristik spesifik untuk produk makanan tertentu karena rasa adalah faktor utama penentu penerimaan konsumen terhadap suatu produk (Sirangelo, 2019). Hasil penilaian panelis terhadap rasa sirup gandaria menunjukkan bahwa perlakuan konsentrasi gula 50, 55, 60, 65 dan $70 \%$, nilai rasa berturut-turut adalah 3,25, 3,26, 3,36, 3,03 dan 2,93 dengan kriteria berasa gandaria. Menurut Zaitoun et al. (2018) bahwa gula berfungsi sebagai pemanis, menyempurnakan rasa asam, dan cita rasa lainnya, disamping itu gula dapat memperbaiki kekentalan. Selain itu, Fungsi utama gula sebagai pemanis mengandung peranan penting karena dapat meningkatkan penerimaan rasa dari suatu makanan (Fitri et al., 2017).

\section{Kekentalan}

Uji organoleptik terhadap kekentalan sirup buah gandaria dilakukan untuk mengetahui tingkat kekentalan minuman sirup yang dihasilkan. Hasil penilaian panelis terhadap kekentalan sirup gandaria menunjukkan bahwa perlakuan konsentrasi gula 50, 55, 60, dan 65\%, nilai kekentalan berturut-turut adalah 2,93, 3,10, 2,73 dan 2,7 dengan kriteria suka sedangkan untuk perlakuan konsen-trasi gula $70 \%$ nilai kekentalan 2,10 dengan kriteria agak suka. Semakin tinggi konsentrasi gula semakin menurun tingkat kesukaan panelis ter-hadap sirup gandaria. Peningkatan kekentalan sirup disebabkan oleh gula mempunyai sifat hidrofilik yang disebabkan oleh adanya gugus hidroksil dalam struktur molekulnya. Gugus hidroksil tersebut akan berikatan dengan molekul air melalui ikatan hidrogen, hal tersebut akan mengurangi aktivitas air dan meningkatkan viskositas (Vaclavic dan Christian, 2014).

\section{Overall}

Overall merupakan uji penerimaan serta uji kesukaan terhadap produk secara keseluruhan, baik dari segi rasa, aroma dan warna (Umam et al., 2012). Hasil penilaian panelis terhadap overall sirup gandaria menunjukkan bahwa perlakuan konsentrasi gula 50, 55, 60, 65 dan $70 \%$, nilai overall berturut-turut adalah 3,10, 3,30, 3,16, 2,93 dan 2,73 dengan kriteria suka. Secara keseluruhan panelis terhadap sirup gandaria dipengaruhi oleh konsentrasi gula.

Pada penelitian ini ditemukan bahwa dengan semakin tinggi penambahan gula menyebabkan tingkat kesukaan panelis menurun. Penurunan penilaian panelis ini diakibatkan oleh penilaian panelis terhadap karakteristik organoleptik yang lain dimana rata penilaian panelis cenderung menurun seiring dengan bertambahnya konsentrasi gula.

\section{KESIMPULAN}

Berdasarkan hasil penelitian dapat disimpulkan bahwa perlakuan konsentrasi gula 55-70\% menghasilkan total gula sebesar 59,36-65,97\%, total asam sebsesar 17,35-13,48\%, vitamin C sebesar $16,97-16,47 \%$, dan total padatan terlarut sebesar 39,27-46,43\%, menghasilkan warna (agak 
kuning-kuning), aroma (agak beraroma gandaria), rasa (agak berasa gandaria-berasa gandaria), kekentalan (agak suka-suka), overall (agak sukasuka). Salah satu perlakuan kosentrasi terbaik adalah perlakuan konsentrasi gula $70 \%$.

\section{DAFTAR PUSTAKA}

Ahmed, A., S.W. Ali, K-ur Rehman, S. Manzoor, S.R. Ayub, and M. Ilyas. 2016. Influence of sugar concentration on physicochemical properties and sensory attributes of sapodilla jam. PeerJ Preprints. DOI: 10.7287/peerj. preprints. $1777 \mathrm{v} 1$.

Akal, C., İ, Buran, R.A. Delialioğlu, and A. Yetişemiyen. 2018. The effect of different sugar ratio on the quality properties of milk jam. The Journal of Food 43: 865-875. DOI: 10.15237/gida.GD18067

[AOAC]. Analytical Methods of Anlysis Association Analitical Chemists. 2005. Washington DC, USA: Association Analitical Chemists.

Andrea, M., I.V.D. Heuvel, and F. Brouns. 2016. Fruits syrup: Sweet concetrated sources. The World of Food Ingredients 44-46.

SNI. 2013. SNI 3544 Sirup. Badan Standarisasi Nasional Jakarta.

Bastanta, D., T. Karo-Karo, dan H. Rusmarilin. 2017. Pengaruh perbandingan sari sirsak dengan sari bit dan konsentrasi gula terhadap sirup sabit. Jurnal Rekayasa Pangan dan Pertanian 5: 102-108. DOI: 10.35891/TP.v11i1.1786.

Fitri, E., N., Harun, dan V.S. Johan. 2017. Konsentrasi gula dan sari buah terhadap kualitas sirup belimbing wuluh (Averrhoa bilimbi L.). JOM Faperta UR 4: 1-13.

Hadiwijaya, H. 2013. Pengolahan Bahan Pangan Dengan Suhu Tinggi. Dasar-Dasar Teori dan Praktek Proses Termal. Pusat Studi Pangan dan Gizi. Institut Pertanian Bogor. Bogor.

Harsono, T., N. Pasaribu, Sobir, and Fitmawati. 2016. Diversity of Gandaria (Bouea) based on morphological characters in Indonesia. SABRAO Jurnal of Breeding and Genetics 48: 504-517.

Hidayat, B.T., A. Wae and N. Andriati. 2018. Physicochemical, sensory attribute and protein profile by SDS-PAGE of beef sausage substitute with texturized vegetable protein. Food Research 2: 20-31. DOI: 10.26656/FR.2017.2(1).106.
Hui Y.H., J. Barta, M.P. Cano, T. Gusek, J.S. Sidhun, and N.K. Sinha. 2006. Handbook of Fruits and Fruit Processing. Blackwell. Ames, Iowa.

Ibrahim, M. 2016. Effect of different storage condition on $\mathrm{pH}$ on vitamin $\mathrm{C}$ content on some selected fruit juices (pineapple, pawpaw and watermelon). International Journal of Biochemistry Research \& Review 11(2): 1-5. DOI: 10.9734/IJBCRR/2016/ 23462.

Magwaza, L. and U. Opara. 2015. Analytical methods for determination of sugars dan sweetness of horticultural products - A review. Scientia Horticulturae 184: 179192. DOI: 10.1016/j.scienta.2015.01.001.

Melisa, R. dan H. Mardesci. 2016. Studi konsentrasi gula yang tepat dalam pembuatan sirup buah kelubi (Eleiodoxa conferta). Jurnal Teknologi Pertanian 5: 3744. DOI: 10.32520/jtp.v5i1.89.

Marwanto, H.S. Gusnawaty, dan Tamrin. 2016. Pengaruh konsentrasi gula kristal dan asam sitrat terhadap karkateristik fisik, kimia dan organoleptik sirup air kelapa. Jurnal Sains dan Teknologi Pangan 1: 209-214. DOI: 10.33772/jstp.v1i3.1547.

Masriatini, R. 2018. Penambahan gula terhadap mutu sirup mangga. Jurnal Online Universitas PGRI Palembang 3: 33-36.

Minh, N. 2014. Various factor affecting to the production of marian plum (Thanh Tra) jam. International Journal of Multidiciplinary Research and Development 1: 127-131.

Nurwin, F.A., E.N. Dewi, dan Romadhon. 2019. Pengaruh penambahan tepung karagenan pada karakteristik bakso kerang darah (Anadara granosa). Jurnal Ilmu dan Teknologi Perikanan 1: 39-46.

Pratama, S.B., S. Wijana, A. Febriyanto. 2012. Studi pembuatan sirup tomarillo (Kajian perbandingan buah dan konsentrasi gula). Jurnal Industri 1: 181-194.

Pujimulyani, D. 2009. Teknologi Pengolahan Sayur-sayuran dan Buah-buahan. Yogyakarta: Graha Ilmu.

Rajan, N.S., R. Bhat, and A. Karim. 2014. Preliminary studies on the evaluation of nutrition composition of unripe and ripe 'Kundang' fruits (Bouea macrophylla Griffith). International Food Research Journal 21: 985-990.

Rajan, N.S., and R. Bhat. 2016. Antioxidant compounds and antioxidant activities in 
unripe and ripe kundang fruits (Bouea macrophylla Griffith). Fruits 17: 41-47. DOI: $10.1051 /$ fruits/2015046.

Rajan, N.S., and R. Bhat. 2017. Volatile constituents of unripe and ripe kundang fruit (Bouea macrohylla Griffith). International Journal of Food Properties 21: 1751-1760. DOI: 10.1080/10942912.2016.1218892.

Sirangelo, T.M. 2019. Sensory descriptive evaluation of food products: A review. Journal of Food Science and Nutritional Research 2: 354-363. DOI: 10.26502/jfsnr. 2642-11000034.

Sudarmadji, S., B. Haryono, dan Suhardi. 1997. Prosedur Analisa untuk Bahan Makanan Dan Pertanian. Edisi ke-4. Yogyakarta: Liberty.
Umam, M. F., R. Utamidan E. Widowati. 2012. Kajian karakteristik minuman sinbiotik pisang kepok (Musa paradisiaca forma typical) dengan menggunakan starter Lactobacillus acidopillus IFO 13951 dan Bifidobacterium longum ATCC 15707. Jurnal Teknosains Pangan 1: 3-11.

Vaclavic, V.A., and E.W. Christian. 2014. Sugars, Sweeteners, and Confections. In: Essentials of Food Science. Springer, 279-295.

Warella, J., P. Papilaya, dan P. Tuapattinaya. 2016. Lama fermentasi terhadap kadar serat nata buah gandaria. Biopendix 3: 33-39. DOI: 10.30598/biopendix vol3issue1 page 33-39

Zaitoun, M., M. Ghanem, and S. Harphoush. 2018. Sugars: types and their functional properties in food and human health. International Journal of Public Health Research 6: 93-99. 